UDC 94

DOI: $10.17748 / 2075-9908-2018-10-5 / 2-173-179$

Viktor A. SHTURBA

Editor-in-Chief Academic Journal “Historical and

Social-Educational Idea"

Kuban State University

Krasnodar, Russia

akademus07@rambler.ru

Evgeniy V. SHTURBA

Kuban State University

Krasnodar, Russia

chook99@mail.ru

Larisa V. ASTANINA

Moscow Institute of Contemporary Academic

Education

Moscow, Russia

rektor@misaoinst.ru

\section{THE FAR EAST IN RUSSIAN HISTORY: END OF THE XX - BEGINNING OF THE XXI CENTURIES}

160 years of inclusion of the Northern Amur Region and 158 years of the Ussuriisk Region's entry into the Russian Empire will be celebrate in 2018, and on October 20 of the same year will be 80 years from the date of the formation of the Khabarovsk and Primorsky Regions. However, not only the jubilee dates, but also the modern development of the Russian Far East as one of the priority national tasks is at the center of attention of representatives of various scientific trends and experts. Among the most important current problems are the search for an answer to the question of how to ensure the development of the territory for the benefit of all of Russia and the Far East community. In the modern cognitive situation, it is important not only to assess the country's economic, demographic, cultural potential and capabilities from the viewpoint of achieving ambitious goals and objectives, but also to adequately assess the role and place in this process of its main participants, historiographical comprehension, as well as the consequences of the adopted programs for the population.

On the pages of the journal "Historical and SocialEducational Idea" for 2018 in the format of a special section "The Far East in Russian History: end of the XX - beginning of the XXI centuries". It is proposed to discuss the following theoretical, methodological and applied problems: scientific concepts, features, participants in the development of the strategy for the development of the Far East; approaches to assessing its implementation in the scientific and expert com-munity; reflection of the consequences of radical market reforms and the results of the implementation of plans for the development of the region in columns and notes, etc. Accordingly, this review article contains an analysis of the corpus of published texts on Far Eastern topics.
ШТУРБА Виктор Александрович главный редактор научного журнала «Историческая и социальнообразовательная мысль»

Кубанский государственный университет г. Краснодар, Россия akademus07@rambler.ru

ШТУРБА Евгений Викторович Кубанский государственный университет г. Краснодар, Россия chook99@mail.ru

АСТАНИНА Лариса Викторовна Московский институт современного академического образования rektor@misaoinst.ru

\section{ДАЛЬНИЙ ВОСТОК В РОССИЙСКОЙ ИСТОРИИ: КОНЕЦ ХХ - НАЧАЛО ХХІ ВВ.} верного Приамурья и 158 лет вхождения Уссурийского края в состав Российской империи, а 20 октября этого же года - 80 лет со дня образования Хабаровского и Приморского краев. Однако не только юбилейные даты, но и современное развитие российского Дальнего Востока как одна из приоритетных национальных задач находятся в центре внимания представителей разных научных направлений и практиков-экспертов. К числу важнейших сегодняшних проблем относятся поиски ответа на вопрос как обеспечить развитие территории во благо всей России и дальневосточников. В современной познавательной ситуации важны не только оценка экономического, демографического, культурного потенциалов и возможностей страны с точки зрения реализации амбициозных целей и задач, но и адекватная оценка роли и места в этом процессе основных его участников, историографического осмысления, а также последствий принятых программ для населения.

На страницах научного журнала «Историческая и социально-образовательная мысль» за 2018 г. в формате специального раздела «Дальний Восток в российской истории: конец XX - начало XXI вв.» публиковались научные статьи по различным теоретико-методологическим и прикладным проблемам: научные концепции, особенности, участники разработки стратегии развития Дальнего Востока; подходы к оценкам ее реализации в научном и экспертном сообществе; отражение последствий радикально-рыночных реформ и результатов осуществления планов развития региона в публицистике и др. Соответственно, данная обзорная статья содержит анализ корпуса опубликованных текстов по дальневосточной тематике. г. Москва, Россия

В 2018 году исполняется 160 лет включения Се- 
Key words: Far East, Russia, modernization, re- ключевые слова: Дальний Восток, Россия, моgional policy, regional identity, sociocultural ра- дернизация, региональная политика, региоrameters, transboundary space нальная идентичность, социокультурные параметры, трансграничность пространства

For citation: Shturba V.A., Shturba E.V., Astanina Для цитирования Штурба В. А., Штурба Е. В., L.V.The Far East in Russian history: end of the XX - Астанина Л.В. Дальний Восток в Российской исbeginning of the XXI centuries. Historical and Social- тории: конец XX - начало XXI вв.. Историческая и Educational Idea. 2018. Vol. 10. No.5-2. PP. 173-179 социально-образовательная $\quad$ мысль. 2018. doi: 10.17748/2075-9908-2018-10-5/2-173-179. Том. 10. № 5 -2 . с. 173-179. (in Russ)

doi: $10.17748 / 2075-9908-2018-10-5 / 2-173-179$.

In 2018 the journal "Historical and Social-Educational Idea" in the format of a special section "The Far East in Russian History: end of the XX - beginning of the XXI centuries" published research papers on various theoretical, methodological and applied problems: scientific concepts, features, and participants in development strategies of the Far East; approaches to assessing its implementation in the scientific and expert community; reflection of the consequences of radical market reforms and the results of regional development plans in journalism, etc. The main thematic segments were historical events in the Far East, modern social-political processes, geopolitical aspects of the transformation of Far Eastern everyday life, the scientific life of the Far Eastern professional community, and responses to published texts.

The article of N.F. Bugai "Public-Political Situation in the Far East: Chinese in the Soviet Construction. 1920-1940th Years" the author writes: "For local governments, party organizations, the primary task in 1920-1930s remained the consolidation of Soviet power. But to solve this problem required a relatively calm atmosphere. Therefore, any aggressive manifestations directed against the Soviets, including in relation to the Chinese, were immediately followed by a response from the organs of Soviet and party power. Already in 1918, the first Soviets were born in the areas inhabited by the Chinese in the Far East. Thus, in the village of Nikolaevka, inhabited by Russians, Chinese, and Koreans, the village council was first elected, by its decision proclaiming "redistribution of land without distinction between nationality and nationality"'” [1]. This publication continues the cycle of scientific articles of this author on ethnic-political and cultural issues [2].

S.K. Pestsov, A.B. Volynchuk in the article "Far East Development Strategy: (Not) Typical Case of Modern Russian Regional Policy" write the following: "Even a superficial analysis of plans and practical actions related to today's turn of the Russian Federation to Asia and the development of the Far East does not give grounds for optimism. The Russian regional policy in its modern form is still rather deaf to these recommendations and seems to be evolving in a way that is different from global trends. This makes the idea of Pacific Russia even less achievable, leaving it in the status of poorly developed peripheral territory for an indefinite time. The development strategy of the Far East, therefore, is an atypical version of the Russian regional policy only in terms of the amount of forces and resources that were used and used for this. But it can be defined as a quite typical example of this policy in terms of dominant approaches, methods and results demonstrating very modest efficiency" [3].

A.S. Vashchuk in the article "Far Eastern Policy of the Post-Soviet Russia in the End of the XX Century and the Beginning of the XXI Century: Concepts, Expert Opinions, and Publicists' Viewpoints" concludes: "The results of the Far Eastern history of the 1990s are expressed in different definitions with a clearly negative color. The relationship between the dominance of the destructive results of socio-economic reforms in the region and the failure of territorial development in the literature is by far the most common historiographic trend. It is revealed through a demonstration of the specifics of the intellectuals of the time of crisis, the specifics of the entire Russian humanitarian space. At the same time, considering the works of historians, we see how the results of expert activities are quickly transformed into a historical source, allowing revealing the possibilities of intellectual history in a regional dimension. Comparative analysis of the results of different genres of publications shows that in the twenty-first century. Far Eastern issues become part of the intellectual national history. The research process of turning Russia to the East, like a mirror, reflects the complex nature of the transition from the paradigm of the integrated development of the productive forces of the region to a spatial economy, with its com- 
ponent uneven development. An analysis of the literature shows the extremely controversial state of that part of society that actively reflects on domestic Russian politics and responds to specific projects and programs. In the XXI century the Far Eastern problems become a kind of "field" where intellectuals are trying to improve their status in the system of relations with the authorities" [4]. The parameters, formats, and strategies of such interactions are analyzed in publications of the Russian political scientist, specialist in the institutional political science T.A. Khalilov [5].

E.S. Volkova in scientific article "Life After Reforms: the Survival Practices in the Russian Far East at the Turn of XX-XXI Centuries in the Mirror of Fiction" indicates that "literary sources clearly demonstrate a catastrophic fall in real money incomes of the population, massive reductions and wage arrears, the collapse of industrial enterprises and entire industries, a sharp stratification of the population and differentiation of geographic space. Deindustrialization, demodernization, destruction of the social infrastructure, primitivization of human existence are all these processes are reflected in the artistic works of the post-Soviet period" [6].

V.G. Petrovich, S.I. Samsonov in the article "The Saratov Volga Region and the Far East: Three Centuries of Relations" write: "It is necessary to adopt a program of labor migration from the densely populated European regions of the country to the Far East, which would provide for the provision of free comfortable housing, relocation at the expense of the state, retraining at the expense of the state for the required professions, guaranteed studies at budget departments of Far Eastern universities for students from among immigrants and local residents, etc." [7].

A.E. Savchenko in the article "In the Search of a Key. The State's Programs of Development of the Russian Far East in the End of XX - in the Early of XXI Centuries" captures the following plots: "Ideas from science and big politics, which were destined to translate into government decisions on the development of the region, concepts and programs, aspirations of regional rulers are all this should be correlated with parallel existing institutions, practices and material structures that create incentives and barriers for the political and economic bureaucracy. Development programs were adopted for various reasons: to consolidate the regional bureaucracy and consolidate the support of the population on the eve of restructuring (1987 Program), to enlist the support of the governor's corps on the eve of the presidential election (1996 Program), to maintain the inertia of massive public investment after completing the preparations for The 2012 APEC Summit. All programs were adopted to the accompaniment of rhetoric about geopolitical importance and the region's great economic potential. But, as experience shows, a development program is not the key that can open the way to realizing the potential of the Far East. A region that occupies almost $30 \%$ of the territory of the largest country in the world and has a population smaller than the city of Moscow alone is capable of absorbing arbitrarily large investments without tangible returns. The programmatic approach may rather be just one of the elements of the Far Eastern policy, designed to solve narrow specific tasks - the development of specific industries and the implementation of local territorial development projects. For the long-term progress of this region it is more important to ensure a stable and favorable macroeconomic environment" [8]. In this context the category "modernization" is essential [9].

E.N. Chernolutskaia in the article "English Language Historiography on Political Transformations in the Russian Far East in the 1990s - Early 2000s" writes that "in the English-speaking historiography of the modern domestic political history of the Russian Far East, the period of the 1990s - early 2000s is clearly distinguished, which also corresponds to the chronology of the studied processes, that is, their scientific understanding was almost real-time. This imposed its own limitations on the formulation of problems, the allocation of aspects, the depth of their analysis, and the sources used, which was also typical of the corresponding national historiography. A number of positions of English-speaking authors are debatable in nature, in the works there are some tendentious assessments. In general, it can be said that in this scientific field only a superficial layer of problems has been worked out with an analysis of the most clearly manifested phenomena and tendencies" [10].

A.G. Amirkhanian, O.I. Borodkina in the article "Social Integration of International Migrants in Primorsky Kray: Problems and Perspectives" write: "Improving the quality of life of the indigenous population of the Primorsky Krai, attracting international labor migrants, creating a regional system of adaptation and integration of migrants are necessary conditions for improving 
the socio-demographic situation in the region and increase the welfare of the population of Primorsky Krai. The support of migrants in the process of adaptation and integration can be carried out through the work of civil society institutions, the development of interaction between nonprofit organizations working with migrants and state institutions. The ethnic diversity of immigrants in the Primorsky Krai should be eliminated, which certainly creates additional difficulties in the integration process. However, the general conclusion that can be made from the results of the study is that, although ethnic identity often cannot but conflict with common civil values, it is necessary to look for compromise solutions to the problems that arise" [11].

V.L. Larin in a scientific article "Pacific Russia in the "Greater Eurasia" at the Beginning of XXI Century: Challenges and Responds" writes: "Once again, the attempts undertaken by the Russian authorities, if not eliminated, then at least reduce the impact of factors causing her fears and anxiety about the fate of eastern margins of the country did not bring the expected result. Time, means and skills for this were clearly not enough. Formal statistical growth did not lead to a general economic development of the region. Its growing economic lag from neighboring China is evident to anyone who at least crosses the Russian-Chinese border, and the continuing outflow of the population testifies in no way to its positive reaction to the policy of the authorities. In Russia, the Eurasian story was manifested in a shift in the attention of the political science community to the discussion of "Greater Eurasia" and a marked decrease in its interest in the Far East. The decline of this interest in the conditions of a cardinally changing geopolitical situation in the region is precisely a new and very real threat to Russia" [12].

E.G. Garbuzarova in the article "The Russian Far East in the Context of the Connection of the Eurasian Economic Union with the Chinese Project "One Belt and One Road": Prospects and Risks" writes: "Russia in the east should solve a double task: promote the development of the Far East with regard to national interests and minimal concessions and also to expand cooperation with China and implement all existing agreements both bilaterally and through the interface of the EAEU and the PIO. On the one hand, the likelihood of Chinese expansion has not disappeared anywhere, but on the other, cooperation between Russia and China is extremely important for the development and stability of the Far East and reducing the likelihood of misunderstanding between the two states. Despite the fact that major transactions concluded by Russia and China remain at the stage of agreement, nevertheless, significant progress in the development of infrastructure and attraction of investments for the economic growth of the Far East is noticeable" [13].

A.S. Vashchuk, S.M. Dudaryonok in the article "Education in the Russian Far East: Stages of the Centenary Way" notes the following points: "Higher humanitarian education before the revolution was of an elite character. The training of historians was carried out at the historicalphilological faculties of universities, where, as well as at law faculties, the majority of teachers were "statesmen". Certain traditions of historical education in the broad sense were laid down in the Far East by the activities of teachers of the Eastern Institute. Later, higher historical education in the Far East of Russia developed in very difficult and dramatic conditions" [14].

A.S. Dybovsky in the article "Alexey M. Pozdneev (1851-1920) and Russian Practical Oriental Studies" writes: "For solving state tasks of organizing the life of new lands, arranging borders and developing relations with neighboring states, the preparation of specialists who speak the languages of eastern suburbs and adjacent Russia states and know geography, economics, politics, legislation, especially the lifestyle and life of the countries and peoples. Since neither the Academy of Sciences nor the universities of Russia were ready to teach living oriental languages and the peculiarities of the societies of the neighboring countries of the Middle and Far East, this required new approaches to the organization of education and science. Through the efforts of perspicacious individuals from among the imperial bureaucracy, the Eastern Institute was opened in Vladivostok on October 21, 1899 to solve the above-mentioned state task, proclaiming its goal to "prepare students in it for service in the administrative and commercial and industrial institutions of East Asian Russia and its adjacent states'”' [15].

V.N. Chernavskaya in the article "Review of the Book "Russia and the Peoples of the Far East: Experience Civilizational and Cultural Interaction (17th $-19^{\text {th }}$ Centuries)". Ed. by V.A. Turaev. Vladivostok: Nauka, 2016. 364 p. ISBN 978-5-9906118-8-7" writes: "The peer-reviewed collective monograph was prepared by members of the Institute of History, Archeology and Ethnography of the Peoples of the Far East, Far Eastern Branch of the Russian Academy of Sciences, 
specialists in history, ethnography, and culture of the Russian Far East, orientalists (specialists in the history of China, Korea, Japan). It addresses five major issues, each of which is devoted to a separate chapter: the indigenous peoples of the Far East in the civilizational space of Russia; ethnic-cultural and ethnic-political aspects of interethnic interaction in the Russian Far East; historical implications of ethnic-cultural contacts; the peoples of East Asia in the ethnic-cultural space of the Russian Far East; The Far East in the historical self-consciousness of the Russian people" [16].

N.M. Platonova in the article "Response to the Column «The Far East in Russian History: End of the XX - Beginning of the XXI Centuries» of the Scientific Journal "Historical and SocialEducational Idea" No. 3, 2018" writes that "the authors' studies published under the heading "The Far East in Russian History: the End of the XX - the Beginning of the XXI Centuries", act as a means of information exchange among historians, political scientists, sociologists, which in modern conditions is an urgent task and practical goal. I hope that the scientific journal and its heading will continue to stimulate new scientific research and become a noticeable act in the development of Russian humanities" [17].

The editors of the scientific journal "Historical and Social-Educational Idea" will continue to cover the most interesting studies of Russian and Foreign scientists on topical social and humanitarian issues.

\section{REFERENCES}

1. Bugai N.F. Public-Political Situation in the Far East: Chinese in the Soviet Construction. 19201940th Years. Historical and Social-Educational Ideas. 2018; 10 (3/1): 13-29. (In Russ.) https://doi.org/10.17748/2075-9908-2018-10-3/1-13-29.

2. Khalilov T.A. Recenzija na knigu izvestnogo istorika N.F. Bugaj o kazakah juga Rossii [Review of the book of the famous historian N.F. Bugay about the Cossacks of South Russia]. Istoricheskaya i sotsial'noobrazovatelnaya mys'l $=$ Historical and Social-Educational Idea. 2015. Vol. 7. No. 6-2. P. 355. (In Russ.).

3. Pestsov S.K., Volynchuk A.B. Far East Development Strategy: (Not) Typical Case of Modern Russian Regional Policy. Historical and Social-Educational Ideas. 2018; 10 (3/1): 82-92. (In Russ.) https://doi.org/10.17748/2075-9908-2018-10-3/1-82-92.

4. Vashchuk A.S. Far Eastern Policy of the Post-Soviet Russia in the End of the XX Century and the Beginning of the XXI Century: Concepts, Expert Opinions, and Publicists' Viewpoints. Historical and Social-Educational Ideas. 2018; 10 (3/1): 30-45. (In Russ.) https://doi.org/10.17748/20759908-2018-10-3/1-30-45.

5. Khalilov T.A. Strategies of Political Interaction between the State and Business Structures in Contemporary Russia. Historical and Social-Educational Ideas. 2015; 7 (6/2): 193-198. (In Russ.) https://doi.org/10.17748/2075-9908-2015-7-6/2-193-198.

6. Volkova E.S. Life After Reforms: the Survival Practices in the Russian Far East at the Turn of XXXXI Centuries in the Mirror of Fiction. Historical and Social-Educational Ideas. 2018; 10 (3/1): 46-57. (In Russ.) https://doi.org/10.17748/2075-9908-2018-10-3/1-46-57.

7. Petrovich V.G., Samsonov S.I. The Saratov Volga Region and the Far East: Three Centuries of Relations. Historical and Social-Educational Ideas. 2018; 10 (3/1): 93-103. (In Russ.) https://doi.org/10.17748/2075-9908-2018-10-3/1-93-103.

8. Savchenko A.E. In the Search of a Key. The State's Programs of Development of the Russian Far East in the End of XX - in the Early of XXI Centuries. Historical and Social-Educational Ideas. 2018; 10 (3/1): 104-113. (In Russ.) https://doi.org/10.17748/2075-9908-2018-10-3/1-104113.

9. Khalilov T.A. Kategorija «modernizacija» v kontekste politologicheskih issledovanij [Category of Modernization in the Context of Political Science Research]. Teorija i praktika obshhestvennogo razvitija $=$ Theory and Practice of Social Development. Krasnodar. 2012. No. 10. Pp. 216-218. (In Russ).

10. Chernolutskaia E.N. English Language Historiography on Political Transformations in the Russian Far East in the 1990s - Early 2000s. Historical and Social-Educational Ideas. 2018; 10 (3/1): 114-123. (In Russ.) https://doi.org/10.17748/2075-9908-2018-10-3/1-114-123.

11. Amirkhanian A.G., Borodkina O.I. Social Integration of International Migrants in Primorsky Kray: Problems and Perspectives. Historical and Social-Educational Ideas. 2018; 10 (3/2): 1323. (In Russ.) https://doi.org/10.17748/2075-9908-2018-10-3/2-13-23. 
12. Larin V.L. Pacific Russia in the "Greater Eurasia" at the Beginning of XXI Century: Challenges and Responds. Historical and Social-Educational Ideas. 2018; 10 (3/1): 65-81. (In Russ.) https://doi.org/10.17748/2075-9908-2018-10-3/1-65-81.

13. Garbuzarova E.G. The Russian Far East in the Context of the Connection of the Eurasian Economic Union with the Chinese Project "One Belt and One Road": Prospects and Risks. Historical and Social-Educational Ideas. 2018; 10 (3/1): 58-64. (In Russ.) https://doi.org/10.17748/20759908-2018-10-3/1-58-64.

14. Vashchuk A.S., Dudaryonok S.M. Historical Education in the Russian Far East: Stages of the Centenary Way. Historical and Social-Educational Ideas. 2018; 10 (4/2): 67-82. (In Russ.) https://doi.org/10.17748/2075-9908-2018-10-4/2-67-82.

15. Dybovsky A.S. Alexey M. Pozdneev (1851-1920) and Russian Practical Oriental Studies. Historical and Social-Educational Ideas. 2018; $10 \quad$ (4/2): 83-105. (In Russ.) https://doi.org/10.17748/2075-9908-2018-10-4/2-83-105.

16. Chernavskaya V.N. Review of the Book "Russia and the Peoples of the Far East: Experience Civilizational and Cultural Interaction $\left(17^{\text {th }}-19^{\text {th }}\right.$ Centuries)". Ed. by V.A. Turaev. Vladivostok: Nauka, 2016. 364 p. ISBN 978-5-9906118-8-7. Historical and Social-Educational Ideas. 2018; 10 (3/2): 24-32. (In Russ.) https://doi.org/10.17748/2075-9908-2018-10-3/2-24-32.

17. Platonova N.M. Response to the Column «The Far East in Russian History: End of the XX - Beginning of the XXI Centuries» of the Scientific Journal "Historical and Social-Educational Idea" No. 3, 2018. Historical and Social-Educational Ideas. 2018; 10 (4/2): 106-111. (In Russ.) https://doi.org/10.17748/2075-9908-2018-10-4/2-106-111.

\section{БИБЛИОГРАФИЧЕСКИЕ ССЫЛКИ}

1. Бугай Н.Ф. Общественно-политическая обстановка на Дальнем Востоке: китайцы в советском строительстве. 1920-1940-е годы. Историческая и социально-образовательная мысль. 2018; 10 (3/1): 13-29. https://doi.org/10.17748/2075-9908-2018-10-3/1-13-29.

2. Халилов Т.А. Рецензия на книгу известного историка Н.Ф. Бугай о казаках юга России // Историческая и социально-образовательная мысль. 2015; 7 (6-2): 355.

3. Песцов С.К., Волынчук А.Б. Стратегия развития Дальнего Востока: (не)типичный случай современной российской региональной политики. Историческая и социальнообразовательная мысль. 2018; 10 (3/1): 82-92. https://doi.org/10.17748/2075-9908-2018-103/1-82-92.

4. Ващук А.С. Дальневосточная политика постсоветской России в конце XX - начале XXI вв.: концепции, экспертные мнения и точки зрения публицистов. Историческая и социальнообразовательная мысль. 2018; 10 (3/1): 30-45. https://doi.org/10.17748/2075-9908-2018-103/1-30-45.

5. Халилов Т.А. Стратегии политического взаимодействия государства и бизнес-структур в современной России // Историческая и социально-образовательная мысль. $2015 ; 7$ (6/2): 193-198. https://doi.org/10.17748/2075-9908-2015-7-6/2-193-198.

6. Волкова Е.С. Жизнь после реформ: практики выживания дальневосточников на рубеже XX-XXI вв. в зеркале художественной литературы. Историческая и социальнообразовательная мысль. 2018; 10 (3/1): 46-57. https://doi.org/10.17748/2075-9908-2018-103/1-46-57.

7. Петрович В.Г., Самсонов С.И. Саратовское Поволжье и Дальний Восток: третье столетие отношений. Историческая и социально-образовательная мысль. 2018; 10 (3/1): 93-103. https://doi.org/10.17748/2075-9908-2018-10-3/1-93-103.

8. Савченко А.Е. В поисках ключа. Программный подход к развитию Дальнего Востока в конце XX - начале XXI века. Историческая и социально-образовательная мысль. 2018; 10 (3/1): 104-113. https://doi.org/10.17748/2075-9908-2018-10-3/1-104-113.

9. Халилов Т.А. Категория «модернизация» в контексте политологических исследований // Теория и практика общественного развития. - Краснодар. 2012. - № 10. - С. 216-218.

10. Чернолуцкая Е.Н. Англоязычная историография о политических трансформациях на Дальнем Востоке России в 1990 - начале 2000-х гг. Историческая и социальнообразовательная мысль. 2018; 10 (3/1): 114-123. https://doi.org/10.17748/2075-9908-2018-103/1-114-123.

11.Амирханян А.Г., Бородкина О.И. Социальная интеграция международных мигрантов в Приморском крае: проблемы и перспективы. Историческая и социально-образовательная мысль. 2018; 10 (3/2): 13-23. https://doi.org/10.17748/2075-9908-2018-10-3/2-13-23. 
12. Ларин В.Л. Тихоокеанская Россия в «Большой Евразии» начала XXI века: вызовы и ответы. Историческая и социально-образовательная мысль. 2018; 10 (3/1): 65-81. https://doi.org/10.17748/2075-9908-2018-10-3/1-65-81.

13. Гарбузарова Е.Г. Дальний Восток России в контексте сопряжения Евразийского экономического союза и китайского проекта «Один пояс - один путь»: перспективы и риски. Историческая и социально-образовательная мысль. 2018; 10 (3/1): 58-64. https://doi.org/10.17748/2075-9908-2018-10-3/1-58-64.

14. Ващук А.С., Дударенок С.М. Историческое образование на Дальнем Востоке России: этапы столетнего пути. Историческая и социально-образовательная мысль. 2018; 10 (4/2): 67-82. https://doi.org/10.17748/2075-9908-2018-10-4/2-67-82.

15. Дыбовский А.С. Алексей Матвеевич Позднеев (1851 1920) и практическое востоковедение России. Историческая и социально-образовательная мысль. 2018; 10 (4/2): 83 105. https://doi.org/10.17748/2075-9908-2018-10-4/2-83-105.

16. Чернавская В.Н. Рецензия на книгу «Россия и народы Дальнего Востока: исторический опыт межэтнического взаимодействия (XVII-XIX вв.)» / отв. ред. В.А. Тураев - Владивосток: Дальнаука, 2016. - 364 с. - ISBN 978-5-9906118-8-7. Историческая и социальнообразовательная мысль. 2018; 10 (3/2): 24-32. https://doi.org/10.17748/2075-9908-2018-103/2-24-32.

17. Платонова Н.М. Отклик на рубрику «Дальний Восток в российской истории: конец XX начало XXI вв.» научного журнала «Историческая и социально-образовательная мысль» № 3 за 2018 год. Историческая и социально-образовательная мысль. 2018; 10 (4/2): 106-111. https://doi.org/10.17748/2075-9908-2018-10-4/2-106-111.

\section{Information about the authors:}

Viktor A. Shturba, Editor-in-Chief, Academic Journal "Historical and Social-Educational Idea", Excellent Specialist of Public Education of RSFSR, Excellent Specialist of Graduate School Education, Doctor of Historical Sciences, Professor, Department of Pedagogy and Psychology, Faculty of Pedagogy, Psychology and Communication Studies, Kuban State University, Corresponding Member of the Russian Academy of Natural Sciences,

Krasnodar, Russia

akademus07@rambler.ru

Evgeniy V. Shturba, Doctor of Historical Sciences, Professor, Department of Pedagogy and Psychology, Faculty of Pedagogy, Psychology and Communication Studies, Kuban State University, President of the Association of Young Scientists of Kuban,

Krasnodar, Russia

chook99@mail.ru

Larisa V. Astanina, Doctor of Historical Sciences, Professor, Rector of Moscow Institute of Contemporary Academic Education,

Moscow, Russia

rektor@misaoinst.ru

Received: 17.10.2018.

\section{Информация об авторах:}

Штурба Виктор Александрович, главный редактор, научный журнал «Историческая и социально-образовательная мысль», отличник народного просвещения РСФСР, отличник образования высшей школы, доктор исторических наук, профессор, кафедра педагогики и психологии, факультет педагогики, психологии и коммуникативистики, Кубанский государственный университет, член-корреспондент Российской академии естественных наук,

г. Краснодар, Россия

akademus07@rambler.ru

Штурба Евгений Викторович, доктор исторических наук, профессор, кафедра педагогики и психологии, факультет педагогики, психологии и коммуникативистики, Кубанский государственный университет, президент Ассоциации молодых ученых Кубани,

г. Краснодар, Россия

chook99@mail.ru

Астанина Лариса Викторовна, доктор исторических наук, профессор, ректор Московского института современного академического образования, г. Москва, Россия rektor@misaoinst.ru

Получена: 17.10.2018. 